\title{
Brain Natriuretic Peptide Response to Six-minute Walk Test in Pulmonary Arterial Hypertension
}

\author{
Zeenat Safdar ${ }^{1 *}$, Vaidehi Kaza ${ }^{2}$, Aishwarya Thakur ${ }^{1}$ and Adaani Frost ${ }^{1}$ \\ ${ }^{1}$ Division of Pulmonary-Critical Care Medicine, Baylor College of Medicine, USA \\ ${ }^{2}$ UT Southwestern Medical Center, USA
}

Submission: August 01, 2019; Published: September 05, 2019

*Corresponding author: Zeenat Safdar, Division of Pulmonary-Critical Care Medicine, Director, Baylor Pulmonary Hypertension Center, Houston Methodist Hospital, Houston, Texas, USA

\section{Abstract}

Background: Brain Natriuretic Peptide (BNP) levels increase in response to exercise in congestive heart failure patients. However, the timing, degree, and clinical consequences of exercise-related BNP elevation in Pulmonary Arterial Hypertension (PAH) remain unexplored.

Methods: A total of 38 consecutive PAH patients were enrolled in this study. BNP levels were drawn prior to, and 6, 14, 20, and 60 minutes following, the six-minute walk test. Subjects were divided based on BNP level cut off used in our laboratory: BNP $\leq 100 \mathrm{pg} / \mathrm{ml}$ and BNP $>100 \mathrm{pg} /$ $\mathrm{ml}$. Time to Clinical Worsening (TTCW) was defined as a composite end point of death, transplant, prostacyclin initiation, or hospitalization for worsening PAH.

Results: Twenty-four patients were in the BNP $\leq 100 \mathrm{pg} / \mathrm{ml}$ group $(44 \pm 28 \mathrm{pg} / \mathrm{ml}$, mean \pm SD) and fourteen patients in the BNP $>100 \mathrm{pg} /$ $\mathrm{ml}$ group $(285 \pm 179 \mathrm{pg} / \mathrm{ml})$. Baseline six-minute walk distance in the $\leq 100 \mathrm{pg} / \mathrm{ml}$ group was higher as compared to the other group ( $\mathrm{P}=0.003$ ). Pre- and post-walk BNP levels did not differ significantly in the two groups. No deaths occurred in the BNP $\leq 100 \mathrm{pg} / \mathrm{ml}$ group, and none of these patients were started on prostacyclin therapy. TTCW was shorter in the $>100 \mathrm{pg} / \mathrm{ml}$ group $(\mathrm{P}=0.005)$ with three deaths and four prostacyclin starts. Higher baseline BNP levels were associated with poor survival $(\mathrm{P}=0.014)$.

Conclusion: Our findings indicate that in PAH patients with elevated baseline BNP levels had a shorter time to clinical worsening, higher mortality, and more prostacyclin initiation. BNP values do not change significantly from baseline values in response to a six-minute walk test. Pre-walk elevated BNP levels are indicator of worse disease rather than post-walk BNP level changes.

Keywords: Right Heart Failure; 6-Min Walk distance; Prognosis; Echocardiogram

Abbreviations: BNP: Brain Natriuretic Peptide; PAH: Pulmonary Arterial Hypertension; TTCW Time to Clinical Worsening; RV: Right Ventricular; 6MWT: Six-Minute Walk Test; PH: Pulmonary Hypertension; WHO FC: World Health Organization Functional Class

\section{Introduction}

Pulmonary Arterial Hypertension (PAH) has a high mortality resulting from right ventricular pressure overload and Right Ventricular (RV) failure [1-5]. RV pressure overload is a stimulus for the release of Brain Natriuretic Peptide (BNP) from ventricles, and reduction in RV pressure overload reduces the BNP levels $[6,7]$. In this regard, an elevated BNP level in PAH is considered a poor prognostic indicator [8,9]. In left heart failure, elevated BNP levels are associated with impaired exercise capacity and poor outcome $[10,11]$. In stable chronic heart failure, BNP levels increase in response to exercise [12]. However, the effects of symptom limited exercise on BNP levels in stable PAH patients remains to be explored.

In PAH patients, the Six-Minute Walk Test (6MWT) is routinely undertaken as an objective measure of exercise capacity [8]. However, the degree, timing, and clinical relevance of changes in BNP levels in relation to the 6MWT has not been explored. In addition, a marginally compensated RV at rest might decompensate with this symptom-limited exercise, producing BNP levels that are higher than resting or baseline levels. Therefore, the aim of this study was to prospectively determine 
whether the changes in BNP levels following a routinely done 6MWT would be indicative of worse outcome in clinically stable PAH patients.

\section{Methods}

After obtaining Investigational Review Board approval and informed consent, consecutive PAH patients were prospectively enrolled at the Baylor Pulmonary Hypertension (PH) program. Patients are routinely followed at approximately 3-month intervals. Inclusion criteria included age $\geq 18$ years, $\mathrm{PAH}$ diagnostic group I, established PAH diagnosis (resting mean pulmonary artery pressure $\geq 25 \mathrm{mmHg}$, pulmonary artery wedge pressure $\leq 15 \mathrm{mmHg}$, and pulmonary vascular resistance $>3$ Woods units by a historical right heart catheterization), and clinically stable disease (no addition or change in PAHspecific medication within the preceding four weeks, or conventional therapy added or changed within two weeks except anticoagulation). Exclusion criteria included systolic blood pressure of greater than $160 \mathrm{mmHg}$ or diastolic blood pressure greater than $100 \mathrm{mmHg}$, musculoskeletal disorders such as arthritis or artificial leg, or any other disease that may significantly limit ambulation, history of symptomatic coronary artery disease or history of atrial septostomy within the preceding three months of study enrolment, and World Health Organization functional class (WHO FC) IV symptoms.

A peripheral Intravenous (IV) cannula was inserted for blood draws. Baseline blood samples were obtained after a 20-minute rest period (immediately prior to walk) and at $6 \mathrm{~min}, 14 \mathrm{~min}$, $20 \mathrm{~min}$, and $60 \mathrm{~min}$ after the end of the 6MWT. When we reviewed data for the first 19 patients, there was no significant difference between baseline and post-walk BNP levels. Therefore, to ensure there was no early increase in the BNP levels, we changed the timing of the blood draw to time 0 (start of walk test), and then $6 \mathrm{~min}, 14 \mathrm{~min}, 20 \mathrm{~min}$, and $60 \mathrm{~min}$ from time 0 (to capture immediate post-walk BNP) for the following 19 patients. BNP levels were compared between the original 19 patients and the subsequent 19 patients. No significant difference in BNP levels were noted between the two blood draw timing cohorts $(6,14$, 20,60 minutes; $p=0.29,0.95,0.58,0.62$ respectively).

Blood was collected in EDTA collection tubes and centrifuged, and the plasma was stored at $20^{\circ} \mathrm{C}$ for analysis. A commercially available immunoassay was used for quantitative BNP determination on an ADVIA Centaur analyser system according to the manufacturer's recommendation. The sensitivity of the assay was $<2.0$ to $5000 \mathrm{pg} / \mathrm{ml}$. Although BNP levels $\geq 180 \mathrm{pg} /$ $\mathrm{ml}$ are considered a poor prognostic indicator [13], we sought to evaluate whether a minimally elevated BNP level may discriminate patients with poor outcome. Subjects were divided based on baseline BNP values. The normal BNP value at our laboratory was $0-100 \mathrm{pg} / \mathrm{ml}$. The cohort was divided across the BNP levels as BNP $\leq 100 \mathrm{pg} / \mathrm{ml}$ and BNP $>100 \mathrm{pg} / \mathrm{ml}$. No other parameter was used to classify the patients.

Demographic and hemodynamic data, Borg dyspnoea score, and WHO FC were recorded at time of study enrolment and at follow-up. The 6MWT was done at study enrolment; follow-up data were obtained at 3 months ( $3.6 \pm 1.7$ months) and at 1 year (12.3 \pm 2 months). Echocardiogram data were recovered from clinically indicated studies done within $2.5 \pm 30$ days (range -79 days to 47 days) of study enrolment, 3 months (range $142 \pm 54$ days), and 1 year (range $387 \pm 59$ days) following study enrolment. No study-related blood testing was performed at follow-up visits. Time to Clinical Worsening (TTCW) was defined as a composite end point of death, transplant, initiation of IV. prostacyclin therapy, or hospitalization for worsening PAH; and these data were collected for up to 3 years following study enrolment. For those patients already on prostacyclin at the time of study enrolment, TTCW was defined at death, transplant, worsening FC, or PAH worsening-related hospitalization and the data were separately analysed.

\section{Statistical Analysis}

Data is presented as means unless otherwise indicated. Descriptive statistics were used to define patient characteristics in the study cohort. To test the relationships between clinical outcomes and BNP and its level at varying time points, logistical regression modelling was applied. ANOVA analysis was conducted to determine differences in the groups with regards to BNP levels. Pearson correlation analysis was also conducted. Kaplan-Meier curves were used to analyse differences in survival, TTCW, hospitalization, and prostacyclin initiation between the two groups using the log-rank test. A p-value $<0.05$ was regarded as statistically significant. Sigma Plot software was used to generate graphs (Sigma Plot 10), and statistical analysis was performed using the SAS 9.2 software package (SAS Institute Inc., Cary, NC).

\section{Results}

\section{Baseline characteristics and demographics}

There were 33 females and 5 males in the study cohort (Table 1). Of these, $58 \%$ of the patients in the BNP $\leq 100 \mathrm{pg} / \mathrm{ml}$ group were WHO FC II, whereas $78 \%$ in the BNP $>100 \mathrm{pg} / \mathrm{ml}$ were WHO FC III. There were more idiopathic PAH patients in the BNP $\leq 100 \mathrm{pg} / \mathrm{ml}$ group ( $\mathrm{p}=0.039$ ). The duration of PAH was $5 \pm 6$ years in the BNP $\leq 100 \mathrm{pg} / \mathrm{ml}$ group and $3 \pm 2$ years in the BNP $>100 \mathrm{pg} / \mathrm{ml}$ group $(\mathrm{p}=0.16)$. There was a trend toward a greater percentage of males in the BNP $>100 \mathrm{pg} / \mathrm{ml}$ group $(\mathrm{p}=0.052)$, and more patients in the BNP $\leq 100 \mathrm{pg} / \mathrm{ml}$ group were on endothelin receptor antagonists.

Table 1: Baseline characteristics of PAH Patients at the time of study enrollment.

\begin{tabular}{|c|c|c|c|}
\hline Characteristics & BNP $\leq \mathbf{1 0 0 p g} / \mathbf{m l}(\mathbf{n}=\mathbf{2 4})$ & BNP $>\mathbf{1 0 0 p g} / \mathbf{m l}(\mathbf{n}=\mathbf{1 4})$ & P value \\
\hline Age, years (Mean \pm SD) & $48 \pm 11.2$ & $52 \pm 13.4$ & 0.388 \\
\hline
\end{tabular}


International Journal of Pulmonary \& Respiratory Sciences

\begin{tabular}{|c|c|c|c|}
\hline Gender, Female, $\mathrm{N}(\%)$ & $23(96 \%)$ & $10(71 \%)$ & 0.052 \\
\hline BMI & $28 \pm 6$ & $25 \pm 4$ & 0.085 \\
\hline \multicolumn{4}{|l|}{ Race, N (\%) } \\
\hline Caucasian & $12(50 \%)$ & $7(50 \%)$ & 0.251 \\
\hline AfricoAmerican & $4(17 \%)$ & $1(7 \%)$ & 0.375 \\
\hline Hispanic & $8(33 \%)$ & $6(43 \%)$ & 0.593 \\
\hline \multicolumn{4}{|l|}{ WHO functional class, $\mathrm{N}$} \\
\hline I & $3(12 \%)$ & $1(7 \%)$ & 0.624 \\
\hline II & $14(58 \%)$ & $2(14 \%)$ & $0.004^{*}$ \\
\hline III & $7(30 \%)$ & $11(79 \%)$ & 0.346 \\
\hline \multicolumn{4}{|l|}{ PAH Etiology, $N$} \\
\hline $\mathrm{iPAH}$ & $14(58 \%)$ & $5(36 \%)$ & $0.039 *$ \\
\hline CHD-PAH & $5(21 \%)$ & $3(21 \%)$ & 0.727 \\
\hline CVD-PAH & $4(17 \%)$ & $5(36 \%)$ & 1 \\
\hline Anorexiogen-PAH & $1(4 \%)$ & 0 & 1 \\
\hline Hereditary PAH & 0 & $1(7 \%)$ & 1 \\
\hline
\end{tabular}

\section{BNP and the six-minute walk test}

In the BNP $\leq 100 \mathrm{pg} / \mathrm{ml}$ group, BNP values were $44 \pm 28 \mathrm{pg} /$ $\mathrm{ml}$ at baseline (range: $8-89 \mathrm{pg} / \mathrm{ml}$ ) and $50 \pm 33,50 \pm 35,46 \pm 28$, and $44 \pm 28 \mathrm{pg} / \mathrm{ml}$ at $6,14,20$, and 60 minutes post-walk test respectively (Figure 1). In the BNP $>100 \mathrm{pg} / \mathrm{ml}$ group, BNP values were $285 \pm 179 \mathrm{pg} / \mathrm{ml}$ at baseline (range: $115-674 \mathrm{pg} / \mathrm{ml}$ ) and $317 \pm 246,298 \pm 221,306 \pm 228$ and $270 \pm 184 \mathrm{pg} / \mathrm{ml}$ at 6,14 , 20 , and 60 minutes post-walk test respectively (Figure 1). The median BNP value for our cohort was $260 \mathrm{pg} / \mathrm{ml}$. BNP levels at the indicated time points compared to the baseline BNP values for both groups did not differ significantly (BNP $\leq 100 \mathrm{pg} / \mathrm{ml}$, $\mathrm{p}=0.51,0.55,0.87,0.99 ; \mathrm{BNP}>100 \mathrm{pg} / \mathrm{ml}, \mathrm{p}=0.70,0.86,0.78$, 0.83 respectively). There was no difference in the percentage increase in BNP levels between the two groups at the indicated time points (6min, $14 \mathrm{~min}, 20 \mathrm{~min}, 60 \mathrm{~min}$; p $=0.74,0.78,0.64$, and 0.24 , respectively). In addition, ANOVA analysis showed that there was a difference between the groups based on baseline BNP levels $(p<0.001)$ but not with regards to post walk BNP levels $(\mathrm{p}=0.149)$. In addition, separating the data based on post walk BNP risers from non-risers using a $10 \mathrm{pg} / \mathrm{ml}$ as a cut off showed no difference between the two groups.

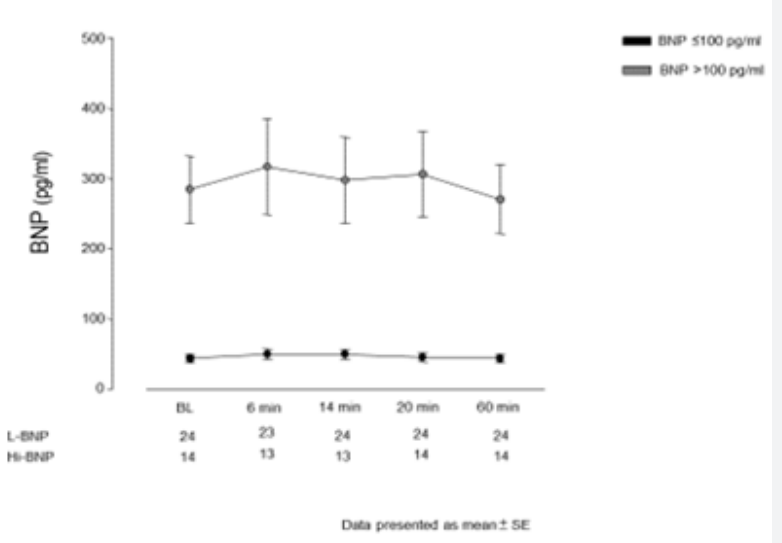

Figure 1: Change in BNP levels in relation to the six-minute walk test. BNP levels drawn at baseline, and at 6 minutes, 14 minutes, 20 minutes, and 60 minutes following the walk test. BL, baseline.

One patient (idiopathic PAH) in the BNP $\leq 100 \mathrm{pg} / \mathrm{ml}$ group showed an increase in BNP to $131 \mathrm{pg} / \mathrm{mL}$ at 6 min post-walk test, and two patients (IPAH and congenital heart diseaseassociated PAH) had BNP elevations at 14 min post-walk (103 and $123 \mathrm{pg} / \mathrm{ml}$ ). These three (BNP $\leq 100 \mathrm{pg} / \mathrm{ml}$ group) patients with post-walk BNP increases had WHO FC II, and experienced no hospitalizations, deaths, or prostacyclin therapy initiations until the time of last follow-up.

Five patients in the BNP $>100 \mathrm{pg} / \mathrm{ml}$ group exhibited a further increase in BNP post-walk (range, 166-832pg/ml). This increase 
reduced to baseline levels within 60 minutes $17 \%$ change as compared to baseline). Two of these patients had IPAH, two had congenital heart disease associated $\mathrm{PAH}$, and one patient had collagen vascular disease-associated PAH. Additionally, two of these five patients had repeated hospitalizations, were started on prostacyclin therapy and later both died. One patient was hospitalized once, started on prostacyclin therapy, and was alive at the time of the last follow-up. The other two patients were alive at the last follow-up, and however one patient was on prostacyclin therapy.

At baseline, 6MWD was $428 \pm 80 \mathrm{~m}$ in the BNP $\leq 100 \mathrm{pg} / \mathrm{ml}$ group and $349 \pm 64 \mathrm{~m}$ in the $\mathrm{BNP}>100 \mathrm{pg} / \mathrm{ml}$ group $(\mathrm{p}=0.003)$
(Figure 2). However, there was no difference in 6MWD at 3 month $(\mathrm{p}=0.12)$ or at 1 year follow up $(\mathrm{p}=0.09)$ between these groups (Figure 2). 6MWD decreased through WHO FC classes I / II to III ( $437 \pm 65$ and $357 \pm 81 \mathrm{~m}$, respectively, $\mathrm{p}=0.001$ ) and BNP levels increased through WHO FC classes I/II to III $(72 \pm 69$ and $200 \pm 203 \mathrm{pg} / \mathrm{ml}$ respectively, $\mathrm{p}=0.01$ ). There was a weak negative correlation between $6 \mathrm{MWD}$ and BNP levels $(\mathrm{R}=-0.34)$. In the BNP $\leq 100 \mathrm{pg} / \mathrm{ml}$ group, the Borg dyspnoea score was $3 \pm 2$ at baseline, $2.6 \pm 1.4$ at 3 month and $2.2 \pm 1$ at 1 year. In the BNP $>100 \mathrm{pg} / \mathrm{ml}$ group, the Borg dyspnoea score was $4.4 \pm 2$ at baseline, $2.7 \pm 1.3$ at 3 months and $2.8 \pm 1.6$ at 1 year. Borg dyspnoea scores did not differ between the two groups at baseline, 3 months, or 1 year $(0.06,0.88$, and 0.25 respectively).

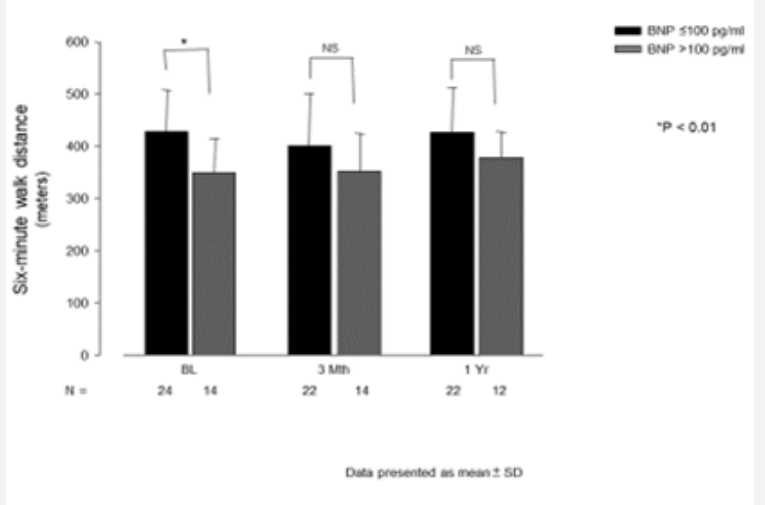

Figure 2: Six-minute walk distance at baseline and at follow-up. Six-minute walk test was conducted at baseline, and at the 3-month and 1-year follow-up. N, number of patients; BL, baseline; $3 \mathrm{Mth}$, 3-month follow-up; 1Yr, 1-year follow-up; NS, not significant. ${ }^{*} \mathrm{P}<0.01$.

\section{Hemodynamic data and BNP levels}

Hemodynamic data is outlined in Table 2. Right ventricular systolic pressure and right atrial pressure were not different between the two groups at baseline, 3 months, and 1 year (Table 3). There was a trend towards a lower cardiac index at 3 months follow-up in the BNP $>100 \mathrm{pg} / \mathrm{ml}$ group $(\mathrm{P}=0.07)$, however, this trend was not lost at 1 year's follow-up.

Table 2: Baseline characteristics of PAH Patients at the time of study enrollment.

\begin{tabular}{|c|c|c|c|}
\hline Characteristics & BNP $\leq 100 p g / m l ~(n=24)$ & BNP >100pg/ml (n=14) & P value \\
\hline Medication use, N & $1(4 \%)$ & $3(20 \%)$ & 0.625 \\
\hline PG & $15(63 \%)$ & $2(14 \%)$ & $0.002^{*}$ \\
\hline ETRA & $3(12 \%)$ & $3(20 \%)$ & 1 \\
\hline ETRA+PG & $3(12 \%)$ & $3(20 \%)$ & 1 \\
\hline ETRA+PDE5-i & $1(4 \%)$ & $2(14 \%)$ & 1 \\
\hline PDE5-i & $1(4 \%)$ & 0 & 1 \\
\hline PDE5-i+PG & 0 & $1(14 \%)$ & \\
\hline CCB & . & & 1 \\
\hline
\end{tabular}

CCB: Calcium Channel Blocker; CHD-PAH: Congenital Heart Disease Associated PAH; CVD-PAH: Collagen Vascular Disease Associated PAH; ETRA: Endothelin Receptor Antagonist; IPAH: Idiopathic Pulmonary Artery Hypertension; N: Number; PDE5-I, Phosphodiesterase 5-Inhibitor; PG: Prostacyclin.

Table 3: Hemodynamic data at baseline and at follow-up in PAH patients.

\begin{tabular}{|c|c|c|c|}
\hline Variables & BNP $\leq \mathbf{1 0 0 p g} / \mathbf{m l}$ & BNP $>\mathbf{1 0 0 p g} / \mathbf{m l}$ & P value \\
\hline Right atrial pressure -BL & $12 \pm 7$ & $13 \pm 5$ & 0.7 \\
\hline Right atrial pressure - 3 month & $10.7 \pm 6$ & $12 \pm 7$ & 0.53 \\
\hline
\end{tabular}


International Journal of Pulmonary \& Respiratory Sciences

\begin{tabular}{|c|c|c|c|}
\hline Right atrial pressure - 1 year & $11 \pm 6$ & $12 \pm 8$ & 0.64 \\
\hline RVSP (mmHg) - BL & $77 \pm 21$ & $94 \pm 47$ & 0.22 \\
\hline RVSP (mmHg) - 3 month & $82 \pm 42$ & $89 \pm 42$ & 0.27 \\
\hline RVSP (mmHg) - 1 year & $77 \pm 39$ & $3.6 \pm 1$ & 0.19 \\
\hline Cardiac output (L/min) - BL & $4.4 \pm 1.2$ & $3.7 \pm 1.8$ & 0.11 \\
\hline Cardiac output (L/min) - 3 month & $4.5 \pm 2$ & $3.7 \pm 1.6$ & 0.11 \\
\hline Cardiac output (L/min) - 1 year & $4.5 \pm 2.3$ & $2.1 \pm .5$ & 0.3 \\
\hline Cardiac index (L/min/m2) - BL & $2.46 \pm .6$ & $2 \pm 1$ & 0.07 \\
\hline Cardiac index (L/min/m2) - 3 month & $2.6 \pm 1.1$ & $2.2 \pm 0.9$ & 0.11 \\
\hline Cardiac index (L/min/m2) - 1 year & $2.6 \pm 1.4$ & & \\
\hline
\end{tabular}

BL: Baseline; RVSP: Right Ventricular Systolic Pressure.

\section{Time to clinical worsening and BNP levels}

The follow up period ranged from 10 to 39 months for the 38 patients enrolled in this study. One patient in the BNP $\leq 100 \mathrm{pg} / \mathrm{ml}$ group underwent lung transplantation 11 months after study enrolment. In the Kaplan-Meier analysis of TTCW, the BNP $>100 \mathrm{pg} / \mathrm{ml}$ group had shorter TTCW compared to the BNP $\leq 100 \mathrm{pg} / \mathrm{ml}$ group (log-rank test, $\mathrm{p}=0.005$ ) (Figure 3 ). No deaths occurred in the BNP $\leq 100 \mathrm{pg} / \mathrm{ml}$ group, and three deaths were noted in the BNP $>100 \mathrm{pg} / \mathrm{ml}$ group ( 2 males and 1 female) (log rank test, $\mathrm{p}=0.014$ ) (Figure 4). There were eight hospitalization events in the BNP $>100 \mathrm{pg} / \mathrm{ml}$ group and four in the BNP $\leq 100 \mathrm{pg} / \mathrm{ml}$ group (Figure 5). Four patients in the BNP $>100 \mathrm{pg} / \mathrm{ml}$ group, and none in the BNP $\leq 100 \mathrm{pg} / \mathrm{ml}$ group, were started on iv prostacyclin therapy (Figure 6). The relationship between clinical outcome in terms of death, hospitalization and prostacyclin initiation, and BNP levels at different time points was determined. This analysis showed that as compared to BNP $\leq 100 \mathrm{pg} / \mathrm{ml}$ group, patients in BNP $>100 \mathrm{pg} / \mathrm{ml}$ group had more deaths and prostacyclin therapy initiations. Higher baseline BNP levels that remained high at 6,20 , and 60 minutes post-walk were associated with poor survival.

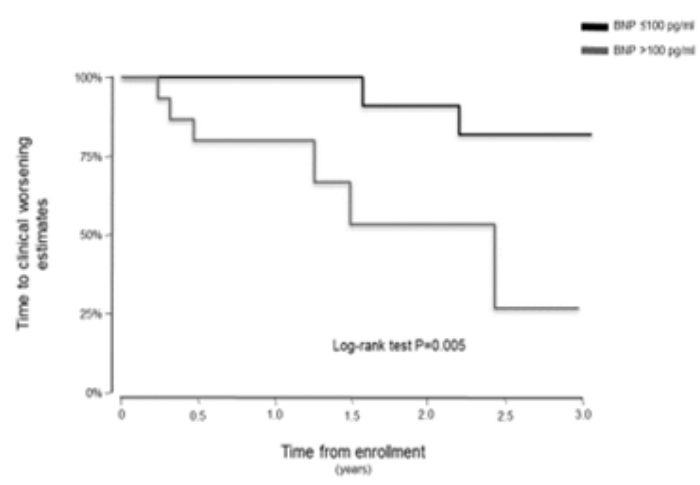

Figure 3: Time to clinical worsening estimates in the two groups. Time to clinical worsening was defined as death, hospitalization or initiation of prostacyclin.

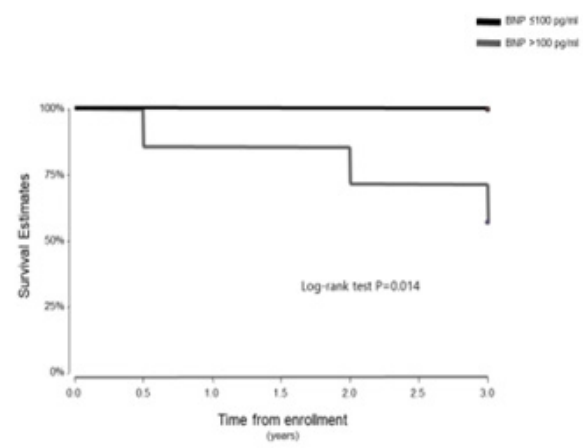

Figure 4: Impact of BNP levels on survival in the two groups. 


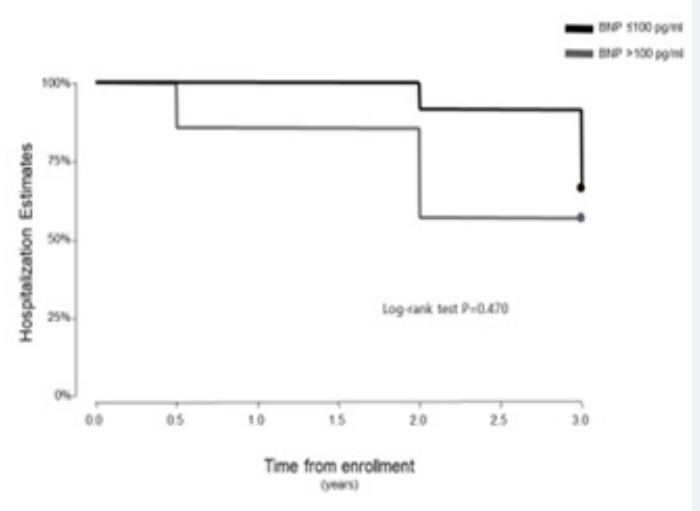

Figure 5: Estimates of hospitalization in the two groups.

Figure 6: Estimates of prostacyclin initiation in the two groups.

\section{Discussion}

In this prospective observational cohort study, elevated baseline BNP levels that increased further after the 6MWT indicated poorer survival. In addition, patients with elevated BNP levels $(>100 \mathrm{pg} / \mathrm{ml})$ at baseline had a greater number of clinical adverse events. However, low resting BNP levels $(<100 \mathrm{pg} / \mathrm{ml})$, even when associated with a small post-walk BNP increase, were not associated with clinical adverse events.

\section{BNP and Exercise}

BNP is secreted as a pro-BNP molecule that gets cleaved to generate a 76-aminoacid N-terminal fragment (NT-PROBNP) and a smaller 32-aminoacid C-terminal active hormone commonly known as BNP [14-19] These two types of BNP are usually tested in a clinical setting; of note the plasma half-life of human BNP is short ( $\sim 20$ minutes) in contrast with the long half-life of NT-BNP (1-2 hours) [14,20] Therefore, changes in BNP levels are considered an indicator of short-term responses to exercise. Additionally, a marginally compensated RV at rest might decompensate with symptom-limited exercise, releasing BNP at higher than resting levels. Since BNP levels may be affected by preceding physical activity, $6 \mathrm{MWT}$ may influence BNP measurement [16]. On the other hand, other natriuretic peptides such as atrial nature tic peptide have not been extensively studied in PAH and are not routinely tested in PAH patients.

The primary stimuli to release BNP is myocyte stretch $[16,21]$, however, BNP synthesis can be augmented by tachycardia [22], glucocorticoid and thyroid hormones [23,24], and vasoactive peptides such as endothelin-1 and angiotensin II, $[25,26]$ independent of the hemodynamic effects of these factors. BNP levels increase with exercise in hypertensive patients and in those with stable chronic heart failure. This incremental BNP increase with exercise was associated with maximal workload and peak exercise [12]. However, in our study, we undertook the measurement of BNP in relation to a walk test (symptomlimited exercise) that is routinely undertaken in PAH patients. It may be possible that with maximal workload, BNP levels may 
show higher incremental increases; however, our aim was to determine the relationship of commonly measured BNP levels to a regularly undertaken walk test.

\section{Patient characteristics and baseline BNP levels}

Patient characteristics were evenly distributed between the two groups, except that there were more males in the BNP $>100 \mathrm{pg} / \mathrm{ml}$ group. This is in line with Registry to Evaluate Early and Long-term Pulmonary Arterial Hypertension Disease Management (REVEAL) data that suggest that male gender is a risk factor associated with worse prognosis $[8,9]$. It is interesting to note that patients with low range BNP levels were more likely to be on an endothelin receptor blocker alone, whereas the distribution of other therapies was similar between the two groups. The clinical significance of this finding is not clear, and a larger study is required to determine the significance of this finding. We envisioned that more patients in the BNP $>100 \mathrm{pg} /$ $\mathrm{ml}$ group would be on prostacyclin therapy, but this was not evidenced in our data. Interestingly, low BNP group had better walk distance and lower WHO FC as compared to the high BNP group. These observations suggest that aggressive PAH therapy should be considered in patients with BNP levels above the normal range $(0-100 \mathrm{pg} / \mathrm{ml})$, and that even a minimally elevated BNP level is an indicator of worse clinical outcome.

\section{Time to clinical worsening}

BNP levels are known to be elevated as a result of right ventricular pressure overload [7]. In our study, minimally elevated $(>100 \mathrm{pg} / \mathrm{ml})$ baseline BNP levels predicted shorter times to clinical worsening. This complements a previous study by Nagaya, which showed that baseline BNP levels were higher in non-survivors [13] Nagaya's study Included Primary Pulmonary Hypertension Patients (IPAH and hereditary), who were followed for up to 24 months. However, our study, in addition to idiopathic PAH patients, included collagen vascular disease, congenital heart disease, and anorexigenic-associated PAH patients, and they were followed for up to 39 months. In the Nagaya study, survival differences were seen in patients with $\mathrm{BNP} \geq 150 \mathrm{pg} / \mathrm{ml}$. In our study, a significant difference was observed using the BNP levels cut-off used in our laboratory (low $<100 \mathrm{pg} / \mathrm{ml}$ vs. high $>100 \mathrm{pg} / \mathrm{ml}$ ). Three patients in the low BNP group (12.5\%) had post-walk increases in BNP levels of $>100 \mathrm{pg} / \mathrm{ml}$ (range: $103-131 \mathrm{pg} / \mathrm{ml}$ ). All three were alive at the time of last follow-up, and none of them were hospitalized for worsening PAH or started on prostacyclin therapy. The clinical significance of these elevations remains unclear. Five patients in the BNP $\leq 100 \mathrm{pg} / \mathrm{ml}$ group (36\%) had increased BNP levels post-walk, and these elevated levels returned to baseline within 60 minutes. Of note, two of these had repeated hospitalizations, were started on prostacyclin therapy, and later died. One patient was hospitalized, started on prostacyclin therapy, and was alive at the time of last follow-up. The last two patients were alive at the time of last follow-up, and one of them was on prostacyclin therapy. It is important to note that BNP levels, if high at baseline, remained elevated post walk; the higher increases in BNP levels were noted immediately following the walk test. Elevated BNP levels that remain elevated 6,20 , and 60 minutes post-walk were associated with poor survival.

\section{Limitations of the study}

In this study, we used 6MWT to determine BNP responses to exercise. It is conceivable that a graded exercise test may have been a better choice to stimulate the atrium and ventricles to secrete BNP instead of a walking test. Probably explaining why, a post exercise differences in BNP was not seen. In addition, including patients with a broader range of PAH severity could have produced different results. It is possible that the BNP response may differ in $\mathrm{PAH}$ patient with varying degree of disease severity. However, stable PAH patients were choosing to participate in this study. A future study will need to be undertaken to determine the BNP responses to exercise in patients with a wide range of PAH severity. Since BNP comes from the RV in $\mathrm{PAH}$, there may be differences in RV function (such as TAPSE, \%area shortening) that may separate patients across the BNP levels. However, these parameters were not measured in this study. Furthermore, changes in atrial natriuretic peptide levels and other natriuretic peptides responses to walk test should be evaluated in future studies $[27,28]$.

\section{Conclusion}

Our study showed for the first time that

a) Minimally elevated BNP levels may be an indicator of worse clinical outcomes,

b) BNP values do not change significantly from baseline values in response to a six-minute walk test, and

c) Elevated BNP levels either pre or post walk are likely an indicator of worsening disease rather than in response to the limited exercise.

\section{Acknowledgement}

The authors wish to thank Mr. Defang Wang, PhD in the section of Health Services Research at Michael E. Debarked Veterans Administration Medical Center, Houston, Texas, for assistance with statistical analysis. The authors also wish to thank Ms. Janice Bristler for editorial support.

\section{References}

1. D’Alonzo GE, Barst RJ, Ayres SM, Bergofsky EH, Brundage BH, et al. (1991) Survival in patients with primary pulmonary hypertension. Results from a national prospective registry. Ann Intern Med 115(5): 343-349.

2. Sandoval J, Bauerle O, Palomar A, Gómez A, Martínez-Guerra ML, et al. (1994) Survival in primary pulmonary hypertension. Validation of a prognostic equation. Circulation 89(4): 1733-1744.

3. Safdar Z (2010) Targeted oral therapies in the treatment of pulmonary arterial hypertension. Clin Drug Investig 30(12): 811-826. 
4. Safdar Z (2011) Treatment of pulmonary arterial hypertension: The role of prostacyclin and prostaglandin analogs. Respir Med 105(6) 818-827.

5. Safdar Z (2011) Effect of transition from sitaxsentan to ambrisentan in pulmonary arterial hypertension. Vasc Health Risk Manag 7: 119-124.

6. Park MH, Scott RL, Uber PA, Ventura HO, Mehra MR (2004) Usefulness of B-type natriuretic peptide as a predictor of treatment outcome in pulmonary arterial hypertension. Congest Heart Fail 10(5): 221-225.

7. Nagaya N, Nishikimi T, Okano Y, Uematsu M, Satoh T, et al. (1998) Plasma brain natriuretic peptide levels increase in proportion to the extent of right ventricular dysfunction in pulmonary hypertension. J Am Coll Cardiol 31(1): 202-208.

8. Benza RL, Miller DP, Gomberg-Maitland M, Frantz RP, Foreman AJ, et al. (2010) Predicting survival in pulmonary arterial hypertension insights from the Registry to Evaluate Early and Long-Term Pulmonary Arterial Hypertension Disease Management (REVEAL). Circulation 122(2): 164-172.

9. Benza RL, Gomberg-Maitland M, Miller DP, Frost A, Frantz RP, et al. (2012) The REVEAL Registry risk score calculator in patients newly diagnosed with pulmonary arterial hypertension. Chest 141(2): 354362

10. Kruger S, Graf J, Kunz D, Stickel T, Hanrath P, et al. (2002) brain natriuretic peptide levels predict functional capacity in patients with chronic heart failure. J Am Coll Cardiol 40(4): 718-722.

11. Tsutamoto T, Wada A, Maeda K, Hisanaga T, Maeda Y, et al. (1997) Attenuation of compensation of endogenous cardiac natriuretic peptide system in chronic heart failure: prognostic role of plasma brain natriuretic peptide concentration in patients with chronic symptomatic left ventricular dysfunction. Circulation 96(2): 509-516.

12. Steele IC, McDowell G, Moore A, Campbell NP, Shaw C, et al. (1997) Responses of atrial natriuretic peptide and brain natriuretic peptide to exercise in patients with chronic heart failure and normal control subjects. Eur J Clin Invest 27(4): 270-276.

13. Nagaya N, Nishikimi T, Uematsu M, Satoh T, Kyotani S, et al. (2000) Plasma brain natriuretic peptide as a prognostic indicator in patients with primary pulmonary hypertension. Circulation 102(8): 865-870.

14. Kemperman H, van den Berg M, Kirkels H, de Jonge N (2004) B-type natriuretic peptide (BNP) and N-terminal proBNP in patients with end-stage heart failure supported by a left ventricular assist device. Clin Chem 50(9): 1670-1672.

15. Nakao K, Mukoyama M, Hosoda K, Suga S, Ogawa Y, et al. (1991) Biosynthesis, secretion, and receptor selectivity of human brain natriuretic peptide. Can J Physiol Pharmacol 69(10): 1500-1506.

16. Bergeron S, Moller JE, Bailey KR, Chen HH, Burnett JC, et al. (2006) Exertional changes in circulating cardiac natriuretic peptides in patients with suggested coronary artery disease. J Am Soc Echocardiogr 19(6): 772-776.
17. Sudoh T, Kangawa K, Minamino N, Matsuo H (1988) A new natriuretic peptide in porcine brain. Nature 332(6159): 78-81

18. Nakamura S, Naruse M, Naruse K, Kawana M, Nishikawa T, et al. (1991) Atrial natriuretic peptide and brain natriuretic peptide coexist in the secretory granules of human cardiac myocytes. Am J Hypertens 4(11): 909-912.

19. Sudoh T, Minamino N, Kangawa K, Matsuo H (1988) Brain natriuretic peptide-32: Nterminal six amino acid extended form of brain natriuretic peptide identified in porcine brain. Biochem Biophys Res Commun 155(2): 726-732.

20. Holmes SJ, Espiner EA, Richards AM, Yandle TG, Frampton C (1993) Renal, endocrine, and hemodynamic effects of human brain natriuretic peptide in normal man. J Clin Endocrinol Metab 76(1): 91-96.

21. Kinnunen P, Vuolteenaho O, Ruskoaho H (1993) Mechanisms of atrial and brain natriuretic peptide release from rat ventricular myocardium: effect of stretching. Endocrinology 132(5): 1961-1970.

22. Qi W, Kjekshus H, Klinge R, Kjekshus JK, Hall C (2000) Cardiac natriuretic peptides and continuously monitored atrial pressures during chronic rapid pacing in pigs. Acta Physiol Scand 169(2): 95-102.

23. Kohno M, Horio T, Yasunari K, Yokokawa K, Ikeda M, et al. (1993) Stimulation of brain natriuretic peptide release from the heart by thyroid hormone. Metabolism 42(8): 1059-1064.

24. Ladenson PW, Bloch KD, Seidman JG (1988) Modulation of atria natriuretic factor by thyroid hormone: messenger ribonucleic acid and peptide levels in hypothyroid, euthyroid, and hyperthyroid rat atria and ventricles. Endocrinology 123(1): 652-657.

25. Bruneau BG, Piazza LA, de Bold AJ (1997) BNP gene expression is specifically modulated by stretch and ET-1 in a new model of isolated rat atria. Am J Physiol 273(6): H2678-H2686.

26. Wiese S, Breyer T, Dragu A, Wakili R, Burkard T, et al. (2000) Gene expression of brain natriuretic peptide in isolated atrial and ventricular human myocardium: influence of angiotensin II and diastolic fiber length. Circulation 102(25): 3074-3079.

27. Leuchte HH, Holzapfel M, Baumgartner RA, Ding I, Neurohr C, et al. (2004) Clinical significance of brain natriuretic peptide in primary pulmonary hypertension. J Am Coll Cardiol 43(5): 764-770.

28. Hama N, Itoh H, Shirakami G, Nakagawa O, Suga S, et al. (1995) Rapid ventricular induction of brain natriuretic peptide gene expression in experimental acute myocardial infarction. Circulation 92(6): 15581564. 

CC (1) Commons Attribution 4.0 License

BY DOI: 10.19080IJOPRS.2019.04.555631
Your next submission with Juniper Publishers will reach you the below assets

- Quality Editorial service

- Swift Peer Review

- Reprints availability

- E-prints Service

- Manuscript Podcast for convenient understanding

- Global attainment for your research

- Manuscript accessibility in different formats ( Pdf, E-pub, Full Text, Audio)

- Unceasing customer service

Track the below URL for one-step submission https://juniperpublishers.com/online-submission.php 